\section{$\underset{\substack{\text { hommes } \\ \text { \& migrations }}}{ }$}

\section{Hommes \& migrations}

Revue française de référence sur les dynamiques

migratoires

1306 | 2014

Ecriture et migration

\title{
Louis-Philippe Dalembert, Ballade d'un amour inachevé
}

Paris, Mercure de France, 2013, 283 pages, 18,90€.

\section{Mustapha Harzoune}

\section{(2) OpenEdition}

Journals

Édition électronique

URL : http://journals.openedition.org/hommesmigrations/2822

DOI : $10.4000 /$ hommesmigrations.2822

ISSN : 2262-3353

Éditeur

Musée national de l'histoire de l'immigration

Édition imprimée

Date de publication : 1 avril 2014

Pagination : 116-116

ISBN : 978-2-919040-27-8

ISSN : 1142-852X

Référence électronique

Mustapha Harzoune, « Louis-Philippe Dalembert, Ballade d'un amour inachevé », Hommes \& migrations [En ligne], 1306 | 2014, mis en ligne le 06 août 2014, consulté le 22 septembre 2020. URL : http:// journals.openedition.org/hommesmigrations/2822 ; DOI : https://doi.org/10.4000/ hommesmigrations.2822

Ce document a été généré automatiquement le 22 septembre 2020.

Tous droits réservés 


\title{
Louis-Philippe Dalembert, Ballade d'un amour inachevé
}

Paris, Mercure de France, 2013, 283 pages, 18,90€.

\author{
Mustapha Harzoune
}

\section{RÉFÉRENCE}

Louis-Philippe Dalembert, Ballade d'un amour inachevé,

Paris, Mercure 2013, 283 pages, 18,90€.

\section{NOTE DE L'ÉDITEUR}

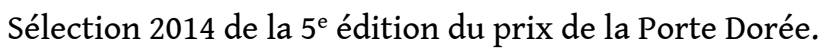

1 Ce nouveau roman de Louis-Philippe Dalembert brille d'abord et paradoxalement d'un amour, lumineux et heureux, celui qui unit Mariagrazia et Azaka. Elle, Italienne pur sucre, poudrière prête à exploser à la gueule des bigots et autres machistes du cru, lui, “ extracom" que l'on suppose d'origine haïtienne, doux et mesuré. On le sait, le bonheur peut dresser des ponts entre les peuples, et le couple finira par amener "un vent d'ailleurs au village des Cipolle". Mais "le malheur sait aussi bien diviser que rapprocher les humains". Le malheur ici, ce n'est pas "la peur et la haine de l'autre", l'entre-soi séculaire de ces montagnards des Abruzzes qui fait de l'étranger un importun, le qu'en-dira-t-on revêche des familles face à une mésalliance, non, le malheur qui frappe à la porte des hommes d'Aquila est un tremblement de terre, celui, tragique, de 2009.

2 Les secousses renvoient Azaka à son propre passé, celui d'un enfant qui à l'âge de 10 ans est resté enseveli, trois jours et trois nuits durant, sous les décombres d'un autre séisme. Une semaine terrible parce qu'elle sera aussi celle de la mise à jour d'un secret de famille et de la perte de l'innocence. Le bonheur comme le malheur participent de la mondialisation. 
De manière originale, Louis-Philippe Dalembert croise un roman sur la migration, l'identité, et ce drame national qui, en Italie, a frappé "avec une égale violence natifs et métèques". La réussite du roman tient autant à sa langue qu'à sa construction: Mariagrazia et Azaka s'aiment et leur amour s'épanouit, alors que la terre gronde, palpite, menace. Tandis que les pouls des cœurs s'accélèrent et battent à l'unisson, résonnent les pulsations de l'écorce terrestre. Tectonique des cœurs versus tectonique des plaques.

4 Malgré les (trop) longues descriptions des séismes, Ballade d'un amour inachevé n'est pas un roman sombre. Louis-Philippe Dalembert peut bien relater deux tremblements de terre meurtriers, évoquer plusieurs drames, dénoncer la montée de l'intransigeance et de la violence racistes, de la bêtise et de l'ignorance xénophobes, il a beau décrire le quotidien de paria des extracoms du Centro storico du village, cette ballade aux accents mélancoliques et tragiques laisse échapper un souffle vital. "Comme si la vie avait décidé de prendre le dessus, serait toujours devant et jamais derrière."

5 La langue n'est pas pour rien dans cette impression. Élégante, précise, sans pathos ni dramatisation excessive, elle est attentive aux gestes du quotidien, aux émotions communes, à hauteur d'homme jusque dans l'usage répété d'expressions italiennes. L'écriture de Louis-Philippe Dalembert rappelle celle tout aussi gourmande de l'Algérien Abdelkader Djemaï, gourmande au figuré comme au propre, avec ces recettes et ces plats qui défilent à foison, ces chansons italiennes et jusqu'à ces notes footballistiques.

6 Oui, malgré le "cirque médiatique" et le "vernis d'œcuménisme" des funérailles nationales, malgré la haine inextirpable du cœur et de l'esprit de ceux qui accusent les extracoms d'être des charognards fouinant dans les décombres, cette Ballade d'un amour inachevé ne parvient pas à désespérer. "Sous quelques cieux qu'il nous ait été de naître et de grandir, nous avons plus ou moins les mêmes qualité et défauts. C'est ce qui fait notre humanité." Parce que et aussi, la vie y est plus forte que la mort. 